\title{
Je t'aime moi non plus The Avotiņš v. Latvia judgment: an answer from the ECrtHR to the CJEU
}

\author{
Tony Marguery* \\ Assistant Professor of European Law at the Europa Institute of Utrecht
}

\begin{abstract}
In the Avotinš v. Latvia judgment the European Court of Human Rights (ECrtHR) rules on the compatibility of mutual trust and mutual recognition ofjudicial decisions with the European Convention of Human Rights (ECHR). This decision was expected especially after the CJEU delivered its Opinion 2/13 on the Draft Agreement on the EU Accession to the ECHR. Mutual trust was indeed one of the arguments of the CJEU to justify the reject of the Draft Agreement. In Avotinš v. Latvia, the ECrtHR revisits its case law on the Bosphorus presumption, which exonerates, under certain conditions, EU Member States from their responsibility under the ECHR when they apply EU law. Although mutual trust implies a reduced control over fundamental rights protection and a quasi-automatic recognition of judicial decisions, the ECrtHR remains confident that the EU protection of these rights is equivalent to the ECHR. The case note shows how the Strasbourg Court draws a line between the effectiveness of the AFSJ on the one hand and the respect for fundamental rights on the other. If the ECrtHR validates the principle of mutual trust it does so at the condition that the respect for the ECHR is not manifestly deficient.
\end{abstract}

\section{Introduction}

The Avotinš v. Latvia Case, is an important judgment of the Grand Chamber of the European Court of Human Rights (ECrtHR) for at least two reasons. Firstly, it is the first time that the ECrtHR had to decide on the responsibility of a EU Member State's action in the implementation of EU law after the 'blow' it received in Opinion 2/13 where the Court of Justice of the

* DOI 10.7590/187479817X14945955771993 1874-7981 2017 Review of European Administrative Law

1 ECrtHR, 23 May 2016, Avotinšs v. Latvia [GC], Application No. 17502/07,

CE:ECHR:2016:0523JUDo01750207; for an interesting analysis, see for example G. Biagioni, Avotinšsv. Latvia, 'The Uneasy Balance Between Mutual Recognition of Judgments and Protection of Fundamental Rights' [2016] European Papers 579. Available at: www.europeanpapers.eu; 'Case Note Avotins v. Latvia', [2016], European Human Rights Law Review, 570-574; J. Emaus, 'The Interaction Between Mutual Trust, Mutual Recognition and Fundamental Rights in Private International Law in Relation to the European Union's Aspiration relating to Contractual Relations', forthcoming in [2017], European Papers. Available at: www.europeanpapers.eu; See also the following blogs: www.eulawanalysis.blogspot.nl/2016/05/eu-law-and-echr-bosphorus- 
European Union (CJEU) condemned the Draft Agreement on the EU Accession to the European Convention of Human Rights (ECHR). Secondly, it is also the first time that the EcrtHR has had to analyse the extent to which the mutual recognition of judicial decisions and its underlying presumption of mutual trust between EU Member States are compatible with the ECHR. ${ }^{2}$ This is important considering the cornerstone status of the principle of mutual recognition in the Area of Freedom, Security and Justice (AFSJ) that the Union is supposed to offer to its citizens ${ }^{3}$ and the constitutional nature of mutual trust affirmed in Opinion 2/13.

The two reasons why the judgment is important are in fact closely linked to each other. Since its judgment in Bosphorus Hava Yollari Turizm ve Ticaret Anonim Sirketi v. Ireland, ${ }^{4}$ the ECrtHR traditionally applies the so-called 'Bosphorus presumption' to exonerate, under certain conditions, EU Member States from their responsibility under the ECHR when they apply EU law. ${ }^{5}$ This presumption is based on a case-by-case consideration made by the ECrtHR that the protection of the individual's fundamental rights provided by EU law is equivalent to the ECHR at the relevant time. It was therefore legitimate to wonder whether the refusal expressed by the CJEU to agree on the accession of the EU to the ECHR would change the conditions of the Bosphorus equilibrium at the time. ${ }^{6}$ As we know, the Bosphorus presumption can be rebutted if the protection of the ECHR is manifestly deficient. The ECrtHR had never had the opportunity to consider how the principle of mutual recognition and mutual

presumption.html; www.gdr-elsj.eu/2014/04/01/cooperation-judiciaire-civile/les-exigencesdu-proces-equitable-face-au-droit-europeen-de-lexequatur-histoire-dun-arretparadoxal/;

www.gdr-elsj.eu/2015/02/12/cooperation-judiciaire-civile/une-deux-et-trois-lectures-de-lavis23013-ue-a-laffaire-avotins-cedh/.

Avotinšs v. Latvia [GC], supra, para. 98.

Article 3(2) TEU, 67 TFEU, Conclusion Tampere.

4 ECrtHR, 30 June 2005, Bosphorus Hava Yollari Turizm ve Ticaret Anonim Şirketi v. Ireland [GC], Application No. 45036/98, CE:ECHR:2005:0630JUDo04503698.

5 See on the Bosphorus doctrine for example, O. de Schutter, 'Bosphorus Post-Accession: Redefining the Relationships between the European Court of Human Rights and the Parties to the Convention', in V. Kosta, N. Skoutaris, V.P. Tzevelekos (eds), The EU Accession to the ECHR, (Oxford and Portland: Hart Publishing, 2014), p. 177 et seq.; T. Lock, 'Beyond Bosphorus: The Euroepan Court of Human Rights' Case Law on the Responsibility of Member States of International Organisations under the European Convention on Human Rights', [2010] Human Rights Law Review 529 et seq.; S Peers, 'Bosphorus European Court of Human Rights', [2006] European Constitutional Law Review 443; K. Kuhnert, 'Bosphorus - Double standards in European human rights protection?’ [2006], Utrecht Law Review, 177-189; A. Hinarejos, 'Case Comment', [2006] European Law Review, 251-258.

6 See in particular the words of the ECrtHR' president, Guido Raimondi in the ECrtHR's 2015 Annual Report qualifying the decision as a 'disappointment', page 36 available at www.echr.coe.int/Documents/Annual_report_2015_ENG.pdf; see also for example D. Halberstam, “It's the Auntonomy, Stupid!" A modest Defense of Opinion 2/13 on EU Accession to the ECHR, and the Way Forward' [2015] German Law Journal 105. 
trust would affect the presumption until the Avotinšs v. Latvia Case. It is precisely the principle of mutual trust that is at the heart of the consideration of the CJEU in its Opinion 2/13. In particular, the CJEU ruled that the accession would be incompatible with the principle of mutual trust. According to that principle, the Member States are presumed to respect the fundamental rights of the individuals. Therefore, a Member State's judicial authority can be requested to recognise and enforce judicial decisions taken by the authority of another Member State without being required to check if the latter did not violate a fundamental right. ${ }^{7}$

With the intensity of the fundamental rights controls being reduced considerably in application of mutual trust, the question was posed whether that system would leave up to the requirement imposed by the ECrtHR or amount to a manifest deficiency. In the present judgment, however, the ECrtHR not only renewed its confidence in the equivalent fundamental rights protection provided by the EU but also considered that Member States were not in principle departing from their obligations towards the ECHR when they are bound by mutual recognition and mutual trust. It considers the principle of mutual trust as wholly legitimate for the creation of an AFSJ. In so doing, the ECrtHR further reduces the intensity of its control of fundamental rights protection when EU law is applied. This being said, that principle must take due account of the guarantees imposed by the ECHR and cannot be applied in a literal and automatic way. Despite the appearances, this limitation follows a trend also present in the recent case law of the CJEU where the principle of mutual trust must take due account of the person's fundamental rights and operates as a limit to the mutual recognition automatism. The case shows that the two European Courts maintain a constructive dialogue fostering coherency and the concerns of individuals. ${ }^{8}$

\section{Facts of the case and the judgment}

An acknowledgement of debt signed in 1999 between F.H. Ltd., a Cypriot commercial company, and Mr Avotiņš, a Latvian national, is at the root of the case. This contract stipulated a choice for the Cypriot law and Cypriot jurisdictions in case a conflict would arise between the parties. In 2003, alleging that Mr Avotiņš had not repaid his debt, F.H. Ltd. brought a proceeding against him before the Cypriot court. By judgement on May $24^{\text {th }} 2004$ the

7 Opinion 2/13, Accession of the European Union to the European Convention for the Protection of

Human Rights and Fundamental Freedoms, EU:C:2014:2454, para. 194.

8 See the words of President Guido Raimondi during the solemn hearing for the opening of the Judicial Year 2017 who refers to the Avotinšs v. Latvia Case. Available at: www.echr.coe.int/Documents/Speech_20170127_Raimondi_JY_ENG.pdf. 
Cypriot court ordered Mr Avotiņš to pay a debt of 100.000 US dollar plus interest to F.H. Ltd. This order was given by default since Mr Avotiņš was indeed not residing at the address of the summons. The fact is unclear whether Mr Avotiņš actually received the summons to attend the hearing. ${ }^{9}$ In any case, Mr Avotiņš claimed that he did not.

In February 2005, F.H. Ltd. applied to the Riga Latgale district court (Latvia) seeking recognition and enforcement of the Cypriot judgment in application of the Brussels I Regulation. ${ }^{10}$ On the 27 th February 2006 , after a lengthy procedure due to the fact that the district court was not satisfied that the address mentioned in the application made by F.H. Ltd. was Mr Avotiñš actual address," this court finally granted the F.H. Ltd.'s request in full without the parties being present. It is not until the 15 th of June 2006 that Mr Avotiņš became aware of the proceedings against him. He immediately appealed against the 27 February 2006 order of the Latvian district court before the Riga regional court, but he did not appeal against the Cypriot judgment of 24th May 2004.

The arguments of the applicant before the regional court were twofold. Firstly, Avotiňš argued that the mutual recognition of the Cypriot judgment was not possible in application of Article 34(2) of the Brussels I Regulation and of the Latvian civil procedure. ${ }^{12}$ Secondly, the recognition of that judgment was only possible if it was made enforceable, which, he contended, was not the case. Indeed, the delivery of the certificate concerning the judgment to be recognised and enforced in application of Brussels I had only happened on the 18th of January 2007 (and over again without mentioning the name of the person against whom the judgment was enforceable). ${ }^{13}$ In the light of these arguments, on October 2nd 2006, the regional court decided to annul the 27 th of February 2006 order of the Latvian district court. F.H. Ltd. appealed against that decision before the Latvian Supreme Court, which by contrast decided that the F.H. Ltd.'s request should be granted in particular because Mr Avotiņš did not appeal

Avotingš v. Latvia [GC], supra, para. 19.

10 Regulation (EC) No 44/2001, of the Council of 22 December 2000 on Jurisdiction and the Recognition and Enforcement of Judgments in Civil and Commercial Matters (OJ 2001, L 12, p. 1).

11 Avotinšs v. Latvia [GC], supra, paras. 21-24.

12 The Latvian civil procedure corresponds in substance to Article 34(2) which, at the time of the proceedings, provided: "A judgment shall not be recognised: 2 . where it was given in default of appearance, if the defendant was not served with the document which instituted the proceedings or with an equivalent document in sufficient time and in such a way as to enable him to arrange for his defence, unless the defendant failed to commence proceedings to challenge the judgment when it was possible for him to do so;". 
the Cypriot judgment when he became aware of it. The Supreme Court therefore quashed and annulled the October 2 nd 2006 regional court judgment.

Mr Avotiņš filed then a complaint against Cyprus and Latvia before the ECrtHR, however only the latter succeeded (the application against Cyprus was out of time) ${ }^{14} \mathrm{Mr}$ Avotins š claimed that his right to a fair hearing guaranteed by Article 6(1) ECHR had been violated by the decision of the Supreme Court to grant the recognition of a judgment that was not enforceable and given in default of appearance. The claim reached the fourth Chamber of the ECrtHR. On February $25^{\text {th }} 2014$, the fourth Chamber decided that Latvia did not violate Article 6(1) ECHR. ${ }^{15}$ The Regulation was presumed to respect the ECHR and relieved the Supreme Court from assessing any further the respect of the ECHR by the Cyprus district court. According to this decision, Latvia had no discretion in the application of the Brussels I Regulation, therefore, the Bosphorus presumption applied. In application of the principle of mutual trust, it was for the country of origin (in this case, Cyprus) to redress a possible violation of the applicant's ECHR's right. Mr Avotiņš had a possibility to appeal the order of the Cypriot court, but he did not do so. Consequently, in conformity with a strict reading of Article 34(2) of the Brussels I Regulation, the Latvian judicial authority was bound to recognise and enforce the order. Mr Avotiņš requested the referral of the case to the ECrtHR Grand Chamber whose judgment is discussed in the present case note.

Before the Grand Chamber, amongst other arguments the applicant contended for two reasons that the Bosphorus presumption could not apply in this case. Firstly, Article 34(2) of the Brussels I Regulation would grant discretion to the Member State of execution. Consequently, the Latvian courts were bound to assess whether the Cypriot court in its judgment of 24 May 2004 had respected Article 6(1) ECHR. Secondly, the Latvian Supreme Court was under the obligation to refer the case to the CJEU, but failed to do so and to motivate this refusal. Because of this failure, the review mechanisms existing in the EU legal system to ensure fundamental rights protection could not develop its full effect.

The Grand Chamber followed the fourth Chamber of the ECrtHR and decided that no violation of the ECHR had occurred in this case. First of all, the ECrtHR recalled that a decision to enforce a foreign judgment falls within the scope of Article 6(1) ECHR. ${ }^{16}$ This consideration also applies when that decision follows the application of the principle of mutual recognition. The control of

\footnotetext{
14 Avotiņš v. Latvia [GC], supra, para. 97.

15 ECrtHR, 25 February 2014, Avotinš v. Latvia, Application No. 17502/o7, CE:ECHR:2016:0523JUDo01750207.

16 Avotinš̌ v. Latvia [GC], supra, para. 98.
} 
the ECrtHR is limited to assess whether the party subject to the judgment had the opportunity to challenge the decision either in the country of origin or in the country of execution. The task of the ECrtHR is not to interpret the application of the Brussels I Regulation or to assess whether the Latvian Supreme Court did apply the Regulation correctly or not. The ECrtHR only assess whether the conditions set by Article 6(1) ECHR have been respected in the proceedings in order to avoid any arbitrariness. ${ }^{17}$ This control however is limited by the Bosphorus presumption. If that presumption applies, then the Latvian Supreme Court is considered as having respected the ECHR unless a manifest deficiency can be shown. There, the ECrtHR refers to its case law applying the Bosphorus presumption, and in particular the Michaud Case decided in 2012. ${ }^{18}$ It makes use of the opportunity to recall that the EU system of fundamental rights protection is equivalent to that of the ECHR from both a substantive and a procedural point of view. The EU offers equivalent protection of fundamental rights standards. In particular, the EU has a Charter of Fundamental Rights of the EU (CFR) which has the same value as the Treaty and through the application of Article 52(3) grants standards of fundamental rights equivalent to that of the ECHR. From a procedural side, the EU system of judicial protection is also satisfactory as far as its full potential has been deployed since it consists of direct and indirect judicial remedies as well as of the specific nature of EU law, i.e. supremacy, (in)direct effect and state liability.

In the present case, the Grand Chamber considers that the presumption applied. Firstly, the Strasbourg Court decides that the EU obligation stemmed from a Regulation, which by definition leaves little room for discretion to Member States. Moreover, as has been interpreted by the CJEU, Article 34(2) of the Brussels I Regulation is very clear and leaves national courts with no margin of manoeuvre. ${ }^{19}$ Secondly, all the mechanisms provided by EU law either through national remedies or EU remedies had been fully deployed in the case. ${ }^{20}$ This observation was not defeated by the fact that the Latvian Supreme Court did not refer the case to the CJEU since it was not required to do so by the parties. Mr. Avotiñš

'did not advance any specific argument concerning the interpretation of Article 34(2) of the Brussels I Regulation and its compatibility with fundamental rights such as to warrant a finding that a preliminary ruling should have been requested from the CJEU.' ${ }^{21}$

Avotingš v. Latvia $[\mathrm{GC}]$, supra, para. 100.

ECrtHR, 6 March 2013, Michaud v. France, Application No. 12323/11, CE:ECHR:2012:1206JUDoo1232311.

Avotinšs v. Latvia [GC], supra, para. 106.

Avotingš v. Latvia [GC], supra, paras. 109-111.

Avotingš v. Latvia [GC], supra, para. 111. 
Finally, the Grand Chamber went into considering whether a manifest deficiency in the protection of Article 6 ECHR could rebut the Bosphorus presumption and consequently whether Latvia should be held accountable for a violation of that provision. In this respect, the ECrtHR considers that in the circumstances of the case Avotins š had a valid remedy available in Cyprus against the Cypriot judgment, but he did not use this remedy although he had the time to do that. ${ }^{22}$ Therefore, the Latvian Supreme Court could not be held responsible for a violation of Article 6(1) ECHR.

\section{Discussion}

3.1 The confidence of the ECrtHR in the EU system of mutual recognition: a fundamental right syllogism

The judgment in Avotinsšv. Latvia makes it clear that the Bosphorus presumption applies to the law of the AFSJ as a whole including where the principle of mutual recognition rules the relations between Member States. Although this conclusion was already implied at the time of the M.S.S.v. Belgium and Greece judgement in $2011^{23}$ or of the Povse v. Austria judgment in $2013^{24}$ the attention paid in the Avotinšs v. Latvia judgment to the provisions and case law concerning the AJSF is considerable not only in the analysis of the relevant EU materials but also in the preliminary considerations of the case's assessment. ${ }^{25}$ The ECrtHR devotes no less than four long paragraphs to mutual recognition, but we will come back to that. ${ }^{26}$ The Strasbourg Court mentions in particular that the principle of mutual recognition, and the underlying mutual trust, not only apply to civil matters but also to criminal matters. The scope of the findings in Avotinš̌ v. Latvia is thus a priori valid when Member States have to apply mutual recognition in EU asylum law, ${ }^{27}$ judicial cooperation in civil matters and in judicial cooperation in criminal matters (for example, in the context of the European Arrest Warrant). The Strasbourg Court gives the stamp of approval

22 Avotinš̌ v. Latvia [GC], cit., para. 120-127.

23 ECrtHR, 21 January 2011, M.S.S. v. Belgium and Greece [GC], Application No. 30696/o9, CE:ECHR:2011:0121JUDo03069609, paras. 335-339 and later ECrtHR, 4 November 2014, Tarakhel v. Switzerland [GC], Application No. 29217/12, CE:ECHR:2014:1104JUDo02921712.

24 ECrtHR, 18 June 2013, Sofia Povse and Doris Povse v. Austria, Application No. 3890/11, CE:ECHR:2013:0618DECooo389011.

25 See in particular Avotinšs v. Latvia [GC], supra, paras. 96-100.

26 Avotinš v. Latvia [GC], supra, paras. 113-116.

27 The Common European Asylum System includes in particular the Dublin Regulation that establishes a system of 'negative mutual recognition' see E. Guild, 'Seeking Asylum: Storm Clouds between International Commitments and Legislative Measures', [2004] European Law Review 198. 
to the position of the CJEU according to which the existence of mutual trust is conditioned, by the premise that Member States share common values, and amongst these values fundamental rights, which as we know consist in particular in the CFR the interpretation of which must be in line with the ECHR in application of Article $52(3)$ and 53 CFR. ${ }^{28}$ Member States are capable of providing equivalent and effective protection of the fundamental rights recognised at EU level. ${ }^{29}$ And in turn the ECrtHR considers that the EU standards of fundamental rights are equivalent to the ECHR. On paper we have the following syllogism: the Member States are bound by EU fundamental rights when they implement mutual recognition, EU fundamental rights are equivalent to the ECHR, therefore mutual recognition is compatible with the ECHR. So it is perfectly legitimate that the AFSJ demands from a national court bound to recognise a judgment made by a foreign counterpart in the EU presumes that the fundamental rights of the person concerned have been or will be fully respected. As the ECrtHR observed in Povse v. Austria the obligation to recognise and enforce a foreign judgment can cause a necessary interference with one fundamental right. $^{30}$

Consequently, the ECrtHR did not find it necessary to assert its jurisdiction because it did not find any change in the protection provided by the EU that is liable to overturn the presumption. It is clear from the judgment that the failure of the EU to accede the ECHR as ordered by Article 6(3) TEU did not call the existence of the presumption into question. ${ }^{31}$ The ECrtHR confirms the continuity of the equivalent protection after Opinion $2 / 13$ and more generally after the entry in force of the Treaty of Lisbon..$^{32}$ This is in particular striking considering that one of the main arguments for the CJEU to reject the Draft agreement was precisely the principle of mutual trust and its new constitutional nature in the AFSJ. Mutual trust also implies that a Member State cannot apply a constitutional standard of fundamental right in order to refuse mutual recognition if that standard is higher than the CFR and compromises the primacy, effectiveness and unity of EU law. ${ }^{33}$ This position is not in favour of increasing fundamental rights protection in Europe unless an increase is proposed either by the CJEU (see Article 52(3) in fine) or the ECrtHR. In addition, the renewed confidence in the EU system does not seem to take account of the claim that the adequacy of the EU system of judicial protection is questionable, especially

\section{Func}$$
30 \text { Sof }
$$

See the explanations of the CFR, S. Peers, T. Hervey, J. Kenner, A. Ward, The EU Charter of Fundamental Rights. A Commentary, Oxford: Hart Publishing 2014, pp. 1490-1503.

See for example C-241/15, Niculaie Aurel Bob Dogi, EU:C:2016:385, para. 33 .

Sofia Povse and Doris Povse v. Austria, supra, paras. 69-87.

A reference to Article 6(3) TEU is made in Avotinš v. Latvia [GC], supra, para. 37.

Avotinš̌ v. Latvia [GC], supra, paras. 101-104.

C-399/11, Stefano Melloni v. Ministerio Fiscal, EU:C:2013:107, para. 60. 
where the CJEU lacks jurisdiction. ${ }^{34}$ In this respect, the Treaty of Lisbon did not really fill certain gaps affecting the mechanisms of judicial control available in the AFSJ. ${ }^{35}$ Firstly, according to Article 24(1) TEU and Article 275 TFEU, the CJEU cannot review acts adopted in application of the Treaty provisions relating to the common foreign and security policy (CFSP) unless that act entails restrictive measures against natural or legal persons. It remains unclear which acts actually are excluded from the CJEU's jurisdiction. ${ }^{36}$ Secondly, with regard to police and judicial cooperation in criminal matters, Article 276 TFEU states that the CJEU has no jurisdiction

'to review the validity or proportionality of operations carried out by the police or other law-enforcement services of a Member State or the exercise of the responsibilities incumbent upon Member States with regard to the maintenance of law and order and the safeguarding of internal security.'

This exclusion originates from the intergovernmental third pillar era ${ }^{37}$ and, therefore, seems at odds ${ }^{38}$ with the 'communitarised' AFSJ where the EU has received rather important powers that necessarily influence the Member States internal security and criminal law policy. ${ }^{39}$ Criminal law is certainly the area where most measures liable to violate fundamental rights are adopted.

Nevertheless, the criticism must be put in perspective. The recent case law of the CJEU (albeit subsequent to the Avotinšs v. Latvia judgment) is progressively

34 K. Lenaerts, 'Le Traité de Lisbonne et la Protection Juridictionnelle des Particuliers en Droit de L'Union', [2009] Cahiers de droit européen, 711-745 ; A. Hinarejos, 'Case Comment', [2006] European Law Review, supra; see also Concurring opinion of Judge Ress in Bosphorus para. 2; T. Ahmed, 'The EU's Protection of ECHR Standards, More Protective than the Bosphorus Legacy?’ in: J. A. Green and C. P.M. Waters (eds.), Adjucating International Human Rights: Essays in Honour of Sandy Ghandi, (Brill-Nijhoff 2014) 99.

35 Other gaps in the judicial protection offered at the EU level that pertained after the Lisbon reform have been pointed out in the literature in particular with regard to the restricted locus standi of individuals to challenge directly EU action before the CJEU, see for example www.jeanmonnetprogram.org/archive/papers/03/031201.pdf; A Arnull, 'Private Applicants and the Action for Annulment since Codorniu’, [2001] Common Market Law Review, 7-52.

${ }_{36}$ The CJEU has decided that the exception provided in these provisions must be interpreted narrowly; see Case C- 658/11, European Parliament and European Commission v. Council of the European Union, EU:C:2014:2025, para. 70; Opinion 2/13, Accession of the European Union to the European Convention for the Protection of Human Rights and Fundamental Freedoms, supra, para. 252.

37 Article 276 copies the wording of the former Article 35(5) TEU.

38 See for example, T.P. Marguery, 'The role of the Charter in European criminal law after Lisbon', [2012] European Law Review, 444.

39 For example to harmonise the criminal law of the Member States and to grant Eurojust with the power to initiate criminal investigations, see Articles 82, 83 and 85 TFEU, see for example, T.P. Marguery, 'European Union Fundamental Rights and Member States Action in EU Criminal Law', [2013] Maastricht Journal of European and Comparative Law, 282-301. 
filing the jurisdictional gap, especially with regard to Article 275. In the $H$ Case, the CJEU ruled that the general exclusion of the CJEU's jurisdiction to review acts adopted in the context of a EU Police Mission for Bosnia and Herzegovina established by a CFSP Decision did not extend to 'acts of staff management relating to staff members seconded by the Member States the purpose of which is to meet the needs of that mission.' It therefore overruled the judgment of the General Court in this case that refused to annul the decision of a Head of the Mission. ${ }^{40}$ More generally, in the recent RosnefCase the CJEU relied on the necessity to respect the right to an effective remedy guaranteed under Article 47 CFR in order to assert its jurisdiction and review the validity of measures adopted in the CFSP following a preliminary reference made by the British High Court of Justice. ${ }^{41}$ In my view, similar developments may well happen with regard to criminal law. Not only Article 47 CFR can bite there, but also the CJEU interprets the scope of application of EU law rather broadly. Such a broad interpretation can have the effect of bringing matters close to national security easily within the ambit of the CFR and consequently under the review of the CJEU. ${ }^{42}$

In any case, where the jurisdiction of the CJEU is excluded, that of ECrtHR will function as a safety net. In the absence of control exercised by the CJEU, for example in breaches stemming from the application of EU primary law the ECrtHR claims its jurisdiction. ${ }^{43}$ One will observe moreover that the Bosphorus presumption is likely not to apply in a case where an issue under 275 (with the exceptions of the two cases abovementioned) or 276 TFEU is raised. Indeed, in such a situation, the discretion to review the protection of fundamental rights remains within the jurisdiction of the Member States. The Bosphorus presumption only applies if two conditions are met. Firstly, the applied EU legislation must leave no discretion to the Member States. Secondly, the supervisory mechanisms provided for by EU law must have been fully deployed, in other words, where the EU control for the respect of fundamental rights fails, the Member States are fully responsible under the ECHR. In this respect, national courts enjoy some discretion to resort to the review of the CJEU. In the Avotinšs 
v. Latvia Case $^{44}$ both conditions were met. If certain aspects of the conditions have been clarified, however, there is still a grey area with regard to the identification of that latter discretion.

\subsection{The conditions for the presumption to apply in a case}

\subsubsection{The obligation to apply EU law without discretion in the context of mutual recognition}

The ECrtHR allows a reduction of its control only if a Member State implements a piece of EU legislation that leaves it with absolutely no discretion. The rationale for this condition is that as long as EU law grants some discretion to a Member State, the ECrtHR can control the actions of that State and does not have to review EU law with a view to apply the ECHR. So, the Avotinss v. Latvia Case clearly posed the question to what extent the obligation of mutual recognition of judicial decisions leaves a Member State without discretion since the Brussels I Regulation implements the principle of mutual recognition of judicial decisions in civil matters. One should recall what the principle of mutual recognition means in the EU legal order although no definition has ever been given in the treaties or in secondary legislation. ${ }^{45} \mathrm{EU}$ secondary legislation can provide that certain judicial decisions made in one Member State (issuing country) must be recognised and enforced by the judicial authorities of another Member State (executing country) unless an explicit ground for non-execution applies. ${ }^{46}$ This obligation must be met even if the justice systems of the Member States are different. ${ }^{47}$

The Avotinšs v. Latvia judgment reveals that EU Member States have a priori no discretion 'where the mutual recognition mechanisms require the court to presume that the observance of fundamental rights by another Member State has been sufficient. ${ }^{48}$ However, this is not self-evident. In order to come to this conclusion, the ECrtHR relies firstly on the quality of the EU instrument implementing mutual recognition that the national court had to apply. The mutual recognition obligation stems from an EU Regulation, which by contrast to a

44 Avotinš̌ v. Latvia [GC], supra, para. 105.

45 E. Herlin-Karnell, The Constitutional Dimension of European Criminal Law, Oxford: Hart Publishing 2012, p. 24; W. de Bondt and G. Vermeulen, 'First things first: Characterising mutual recognition in criminal matters', in: M. Cools (ed.), EU Criminal Justice, Financial \& Economic Crime: New Perspectives, (Maku 2011) 17.

46 For an exhaustive research on that principle, see for example C. Janssens, The Principle of Mutual Recognition in EU Law, Oxford: Oxford University Press 2013.

47 See for example in criminal justice, Joined cases C-187/01 and C-385/01, Hüseyin GözütokandKlaus Brügge, EU:C:2003:87, para. 33.

48 Avotinš̌ v. Latvia [GC], supra, para. 115. 
Directive, does not leave much room to the Member States for their implementation. Secondly, Article 34(2) provided in this Regulation as interpreted by the CJEU did not leave any doubt as to the conditions for a refusal to recognise and enforce a foreign judgment. ${ }^{49}$ Finally, the Recitals of the Brussels I Regulation leaves no doubt as to the automaticity of the system and provides that

'the declaration that a judgment is enforceable should be issued virtually automatically after purely formal checks of the documents supplied, without there being any possibility for the court to raise of its own motion any of the grounds for non-enforcement provided for by this Regulation. ${ }^{50}$

Three factors seem thus important in order to identify the extent to which a Member Sate is bound by mutual recognition without discretion: the legal effects of the instrument, the particular provision in that instrument imposing mutual recognition as interpreted by the CJEU and the automaticity of the mechanism..$^{1}$

The fact that the EU obligation stems from a particular instrument rather than another is important but not determinant in the identification of the margin of discretion that Member States enjoy in order to be covered by the Bosphorus presumption of equivalence. Consequently, a Regulation can leave some discretion to the Member States. This was for example the case of the 'sovereignty clause' in the Dublin II Regulation. ${ }^{52}$ It remains however unclear to what extent, for example a Framework Decision in criminal matters, which, with the exception of the absence of direct effect, is very similar to a Directive, would provide the necessary discretion to Member States in order to hold them accountable. ${ }^{53}$ In particular, the Framework Decision on the European Arrest Warrant (EAW) provides a list of grounds for non-execution of such a warrant. ${ }^{54}$ Although, national authorities are free to choose the form and methods for its implementation, it is settled case law that the grounds for non-execution of a

Avotinš v. Latvia [GC], supra, para. 106.

Avotingš v. Latvia [GC], supra, para. 113 .

See for an analysis of automatic recognition in the various fields of EU law where mutual recognition applies, D. Düsterhaus, 'Judicial Coherence in the Area of Freedom, Security and Justice - Squaring Mutual Trust with Effective Judicial Protection' [2015] Review of European Administrative Law, 161-182.

52 M.S.S. v. Belgium and Greece [GC], supra., paras. 339-340.

53 S. Prechal and T. Marguery, 'La mise en œuvre des décisions-cadres une leçon pour les futures directives pénales ?', in: J. Dutheil de la Rochère (ed.), L'exécution du droit de l'Union, entre mécanismes communautaires et droits nationaux, (Bruylant, Bruxelles 2009) 225-251.

54 Council Framework Decision 2002/584/JHA of 13 June 2002 on the European arrest warrant and the surrender procedures between Member States (OJ 2002 L 190, p. 1), as amended by Council Framework Decision 2009/299/JHA of 26 February 2009 (OJ 2009 L 81, p. 24). 
EAW are exhaustively enumerated. ${ }^{55}$ Amongst these grounds, the Framework Decision does not provide for a human rights based ground for refusal. Should a Member States be considered as enjoying discretion when, notwithstanding this case law, it provides such a human rights grounds for refusal in the legislation implementing the EAW ${ }^{56}$ What about EU legislation that sometimes provides no grounds for non-execution, ${ }^{57}$ grounds for optional non-execution ${ }^{5}$ or grounds for mandatory non-execution?

The ECrtHR seems to attach only attention to the provision relied on in the case. So the fact alone that there are grounds for non-execution applicable in the EU instrument implementing mutual recognition does not necessarily mean that the national court enjoys discretion. In Avotinšs v. Latvia for example, only Article 34(2) of the Regulation was at stake. Article 34(1) of the Regulation that allows for non-recognition of a judgment in violation the Member State's public policy did not deserve the attention of the ECrtHR although the nonrecognition could have been based on this ground. ${ }^{59}$ By contrast, the total absence of such grounds can trigger Bosphorus. In Povse v. Austria, the absence of grounds for non-execution concerning the recognition of a certified judgment ordering a child's return under Regulation 2201/2003 indicated that the national court did not enjoy any discretion. ${ }^{60}$ Nevertheless, as we will see, this finding was justified by the existence of other safeguards.

In fact, what matters is the extent to which the specific provision of the EU law implemented in the case imposes automatic mutual recognition. ${ }^{61}$ The automatism in the mutual recognition is only possible if this does not undermine the protection guaranteed by the ECHR for the presumption to apply. Mutual recognition consequently requires that the judgment does not violate fundamental rights. A judicial control must be possible. As we will see the existence of a manifest deficiency of the ECHR that can overrule the Bosphorus presumption can depend from an answer to that question. This is precisely the reason why the ECrtHR pays particular attention to the respect of the second

55 See for example, Case C-237/15 PPU, Minister for Justice and Equality v. Francis Lanigan, EU:C:2015:474, para. 36 .

56 This is the case in several Member States, for example, Article 11 Dutch Surrender Act or Article 73 of the Law on international mutual legal assistance in criminal matters.

57 Council Regulation (EC) No 2201/2003 of 27 November 2003 concerning jurisdiction and the recognition and enforcement of judgments in matrimonial matters and the matters of parental responsibility, repealing Regulation (EC) No 1347/2000 (OJ 2003 L 338, p. 1).

58 FD EAW article 4, FD 2008/909 or FD 2008/947.

59 Avotinš v. Latvia [GC], supra, para. 108.

60 Sofia Povse and Doris Povse v. Austria, supra, para. 79.

61 V. Mitsilegas, 'The Limits of Mutual Trust in Europe's Area of Freedom, Security and Justice: From Automatic Inter-State Cooperation to the Slow Emergence of the Individual', [2012] Yearbook of European Law, 319 . 
condition for the presumption to apply: the deployment of the full potential of the supervisory mechanism provided by EU law.

\subsubsection{The discretion in the obligation to refer to the CJEU}

Among all the mechanisms provided by EU law to supervise the respect of fundamental rights, ${ }^{62}$ the ECrtHR considers two aspects essential. First of all, in the context of mutual recognition, the control of the merits of the case in the light of fundamental rights should happen as much as possible in the country which has issued the judgment the enforcement of which is sought. In this respect, both the CJEU and the ECrtHR agree. ${ }^{6}{ }_{3}$ Secondly, if there are any doubts either on the validity of the EU instrument imposing mutual recognition or its interpretation in the light of fundamental rights, national courts enjoy the faculty (and sometimes have the obligation) to refer a question to the CJEU in the context of a case pending before it.

EU law imposes a duty on the Member States to respect EU fundamental rights as soon as they act within the scope of EU law. ${ }^{64}$ So when making a judgment that will have to be enforced in another Member State, the court of the issuing country must make sure that the fundamental rights of the individual concerned by the judgment are respected. If this individual complains that his or her right has been violated, this person will first have to use all the remedies available in that country. From the point of view of Strasbourg this is in line with the principle that the ECHR is only applicable within the jurisdiction of the States party to it. An EU Member State is, in principle, only accountable for its acts within its territory. ${ }^{65}$ In this respect, the ECrtHR takes into account the provisions enshrined in the relevant EU legislation to this end. For example, in Povse v. Austria, the Strasbourg Court was satisfied with the minimum requirements contained in Article 42(2) of Regulation 2201/2003 obliging the

62 These mechanisms are listed in the ECrtHR judgment of 30 June 2005, Bosphorus Hava Yollari Turizm ve Ticaret Anonim Şirketi v. Ireland [GC], Application No. 45036/98, paras. 160-164 and concern in particular the action for annulment, the action against the EU for failure to act, the plea of illegality, state liability and other means of judicial protection such as direct effect and consistent interpretation.

63 See for example Case C-211/10, Doris Povse v. Mauro Alpago, EU:C:2010:400 and Sofia Povse and Doris Povse v. Austria, supra, paras. 80-81; Case C-168/13 PPU, Jeremy F v. Premier minister, EU:C:2013:358, para. 50; ECrtHR, 4 May 2010, Stapleton v. Ireland, Application No. 56588/07, CE:ECHR:2010:0504DEC005658807 (in this case, the ECrtHR made its observation in a decision on the inadmissibility of the application).

64 T.P. Marguery, 'European Union Fundamental Rights and Member States Action in EU Criminal Law', supra.

65 See for example about the scope of the ECHR in criminal matters, A. van Hoek and M. Luchtman, 'Transnational cooperation in criminal matters and the safeguarding of human rights', [2005] Utrecht Law Review, 1-39. 
court making a decision on the return of a child that has been wrongfully removed. ${ }^{66}$ In application of this provision, the issuing court had to make sure that the child and the parties to the case had enjoyed the right to be heard. The ECrtHR does not seem to impose exhaustive requirements to be respected by the issuing country however and relies on the national system to make sure that the ECHR will be safeguarded. So it is certainly a good thing although not a necessity that EU legislation implementing mutual recognition obliges the issuing country to respect fundamental rights when making the judicial decision that has to be recognised. The more automatic the obligation of mutual recognition is (for example, when non-recognition is banned), the more advisable it is for the EU legislator to impose minimum requirements on the issuing country for the review of fundamental rights in the decision-making process.

In any case, if the implementation of EU law gives rise to a risk of fundamental right violation in the case pending, the national court has the right and sometimes the obligation to ask for the guidelines of the CJEU. This faculty is both open in the country issuing the judgment and in the country bound to enforce it. Therefore, it is essential for the purpose of applying the Bosphorus presumption that the faculty to refer a question has been fully exercised. A preliminary reference is an obligation for a national court if a question of validity of EU law is at stake ${ }^{67}$ or if the national court that decides the case is a court against whose decision no judicial remedy under national law exists. In application of Article $267(3)$ TFEU that national court has an obligation to refer to the CJEU unless the same question has already been answered by the CJEU in a previous case or the interpretation of EU law does not leave any room for interpretation. ${ }^{68}$ However the obligation to make a reference arises as soon as the judge perceives either of his own motion or at the request of the parties that the litigation depends on the interpretation or validity of EU law. ${ }^{69}$ In other words, a national court, whether of last instance or not, ${ }^{70}$ has the discretion to assess if a reference is necessary to enable it to give judgment. The scrutiny exercised by the ECrtHR on the use of this discretion is complicated and seems at odds with an adequate protection of the individual's rights.

66 Sofia Povse and Doris Povse v. Austria, supra, para. 80, see M. Hazelhorst, 'The ECtHR's decision in Povse: guidance for the future of the abolition of exequatur for civil judgments in the European Union' [2014] Nederlands Internationaal Privaatrecht, 27-33.

67 Case 314/85, Foto-Frost v. Hauptzollamt Lübeck-Ost, EU:C:1987:452.

68 In particular the Case 283/81, Srl CILFIT and Lanificio di Gavardo SpA v. Ministry of Health, EU:C:1982:335.

69 Case 166/73, Rheinmühlen-Düsseldorf v. Einfuhr- und Vorratsstelle für Getreide und Futtermittel, EU:C:1974:3, paras. 3 and 4 .

70 Case 283/81, Srl CILFIT and Lanificio di Gavardo SpA v. Ministry of Health, supra, para. 10. 
There are several scenarios where the ECrtHR has clarified the application of the Bosphorus presumption in the context of the preliminary reference procedure. First of all, when a national court has referred a question concerning the respect of fundamental rights in the case pending, then it is bound to apply the CJEU's answer and does not enjoy any discretion. This was the Bosphorus scenario. ${ }^{71}$ The presumption applies.

By contrast, the presumption is not automatically applying where a national court refused to refer to the CJEU although a party requested a reference to be made. Where EU law does not leave any discretion to a Member State, the question whether Bosphorus will protect the Member State depends on the necessity to ask a question to the CJEU for the purpose of ensuring the full respect of fundamental rights. A refusal to refer does not always defeat the presumption. It may constitute a violation of Article 6(1) ECHR as such if the court failed to provide the reasons for the refusal, ${ }^{72}$ and still the national court can be considered as not having departed from the ECHR for the purpose of applying Bosphorus. The ECrtHR assesses whether it would have been necessary for that court in order to fully respect fundamental rights in the application of EU law to refer a question in the case pending. The necessity could have occurred either because the question has never been decided by the CJEU or because a previous case from the CJEU although concerning the same EU instrument did not rule on the particular fundamental right at stake in the case.

In Avotinšs v. Latvia the ECrtHR considered another scenario. That is the situation of an individual failing to ask the national court to make a reference and the court not asking such a question on its own motion although it was in last instance. In that case, the intensity of the control exercised by the ECrtHR on the national court's discretion not to refer to the CJEU is reduced. When the parties do not request a reference, the ECrtHR does not exercise a full review of the judge's discretion, Bosphorus applies. This is regrettable especially because asking for a preliminary reference to be sought is not a right established under EU law for the individuals. It seems that Avotiņš did not even have the

This is what happened in Bosphorus Hava Yollari Turizm ve Ticaret Anonim Şirketi v. Ireland, supra and more recently in Sofia Povse and Doris Povse v. Austria, supra, para. 81.

72 The failure to provide reasons when rejecting a request to make a preliminary reference to the CJEU is a breach of Article 6(1) ECHR, see ECrtHR, 8 April 2014, Dhahbi v. Italy, Application No. 17120/09, CE:ECHR:2014:0408JUDo01712009. Since rather recently, the ECrtHR considers that the refusal to refer a question to the CJEU can give rise to a violation of the right to access to justice if the refusal is arbitrary and without reason, see ECrtHR, 20 September 2011, Ullens de Schooten and Rezabek v. Belgium, Application No. 3989/07 and 38353/07,

CE:ECHR:2011:0920JUDo00398907; ECrtHR, 21 July 2015, Schipani and others v. Italy, Application No. 38369/09, CE:ECHR:2015:0721JUDo03836909; see C. Lacchi, The ECrtHR's Interference in the Dialogue between National Courts and the Court of Justice of the EU: Implications for the Preliminary Reference Procedure', [2015] Review of European Administrative Law, 95-125. 
opportunity to request that a ruling should be sought because only the other party had been allowed to make submissions at the hearing of the Supreme Court. ${ }^{73}$ Moreover, the ECrtHR is well aware that individual access to the CJEU is limited. In particular, the standing of individuals to challenge EU acts is limited in application of Article 263 TFEU. ${ }^{74}$ One may wonder whether it would not have been more protective of the individuals' rights that the ECrtHR asserts a right under the ECHR to a reference from national courts against whose judgment there is no national remedy. ${ }^{75}$ In any case, these considerations clearly show not only deference in the judicial dialogue established by the Treaty but also confidence in the duty of sincere cooperation binding on Member States' courts. ${ }^{76}$ As already said that confidence extends also to the principle of mutual trust underlying the whole system of mutual recognition. Nevertheless, the confidence is not absolute and under certain conditions can be rebutted. This is the case when the principle of mutual trust implies that the mutual recognition mechanism is automatic and that the system of fundamental right's control is manifestly deficient.

\subsection{Can the principle of mutual trust entail a manifest deficiency in the protection of the ECHR?}

The judgment in Avotinšsv. Latvia reiterates that the presumption could be rebutted if it is considered that the protection of the ECHR is manifestly deficient. ${ }^{77}$ In that situation, a national court must let the European Convention's obligations prevail over its EU obligations. Put differently, if a national court was to find that while abiding by its obligations under EU law the protection of a particular European Convention right would be manifestly deficient that court would have to set aside its obligations under EU law. What does this mean in the context of mutual recognition?

Before dwelling into the circumstances of the case, the ECrtHR made general considerations on the principle of mutual recognition. ${ }^{78}$ The Strasbourg Court acknowledges that mutual recognition is based on the principle of mutual trust existing between the EU Member States and that these principles are an essential part of the EU system. Nevertheless, the Strasbourg Court observes

73 Avotiņš v. Latvia [GC], supra, para. 74.

74 See Case 25/62, Plaumann a Co. v. Commission of the European Economic Community, EU:C:1963:17; the severity of this test in the light of an effective judicial protection has long been criticized, the Treaty of Lisbon addressed some aspects of the gaps, but not entirely, see literature footnote 34 supra.

75 See S. Peers, 'Bosphorus European Court of Human Rights', supra.

76 Article 4(3) TEU.

77 Avotinsš v. Latvia [GC], supra, para. 112.

78 Avotinšs v. Latvia [GC], supra, paras. 113-116. 
that there is a tension between the effectiveness of these principles and the respect for fundamental rights. The two presumptions, i.e. mutual trust and Bosphorus, result in a twofold limitation of the national court's power to review the respect of fundamental rights. Therefore, the ECrtHR imposes limits to this effectiveness and must "verify that the principle of mutual recognition is not applied automatically and mechanically [...] to the detriment of fundamental rights. ${ }^{79}$ The implementation of these principles must not be allowed if the protection of individuals' fundamental rights is undermined, this could otherwise amount to a manifest deficiency in the application of the ECHR. The argument refers to the concerns already mentioned that the principle of mutual recognition of judicial decisions should not be a mechanism allowing for an automatic recognition of these decisions without any possibility to control that the ECHR was duly respected. Mutual recognition should not boil down to having a blind trust in how other Member States protect the rights of the individuals. The EU and its Member States may well abide by the ECHR in abstracto, but this should not prevent a Member State's court to look into the particular circumstances of a case for a violation of a fundamental right. The question then is when exactly will such a violation rebut the trust that this court must have in its foreign counterpart? And if there is a rebuttal of the principle of mutual trust what does that mean for mutual recognition? The ECrtHR observes that

'if a serious and substantiated complaint is raised before [national courts] to the effect that the protection of a Convention right has been manifestly deficient and that this situation cannot be remedied by European Union law, they cannot refrain from examining that complaint on the sole ground that they are applying EU law. ${ }^{80}$

This seems to imply that a serious and substantiated complaint concerning a fundamental right violation can be raised by one of the parties to the pending case. In my view, the general obligation that Member States have towards the ECHR also implies that a national court bound by mutual recognition can have suspicion that a breach of fundamental rights has or will occur in the issuing Member State, and therefore raise the question on its own motion.

In practice, as has been shown it is for that State to remedy the breach or for the competent court to refer the case to the CJEU. Nevertheless, if the existence of a manifest deficiency in the protection is shown, EU law must be set aside. Firstly, it is unclear what kind of evidence a court should consider as

8o Avotiņš v. Latvia [GC], supra, para. 116 (italics added). 
sufficiently serious and substantiated. Secondly, what a manifest deficiency is remains rather vague. There is no definition of that concept. So it is uncertain when the system is deficient, and when that deficiency is so evident that it becomes manifest. ${ }^{81}$ The Avotinš v. Latvia judgment did not plainly explain the concept, but clarified certain aspects of it.

Following this case, the ECrtHR seems to impose a duty on national courts to control the compatibility with the ECHR firstly of the provision of EU law implementing mutual recognition and secondly of its implementation in the case pending. The provision of EU law according to which a Member State is bound to recognise and enforce a foreign judgment must itself be compatible with the ECHR. If there is a doubt as to the validity of that provision then the national court is bound to refer to the CJEU. In Povse v. Austria, after the CJEU decided on the question, the existence of a provision in the Regulation 2201/2003 imposing minimum fundamental rights requirements on the issuing country was sufficient to rule out a manifest deficiency. In other words, if a national court were to find the existence of manifest deficiency, it would have to refer it to the CJEU. In my view, although unlikely to happen considering the renewed confidence in the equivalent protection offered by the EU, a national court could still be bound to refuse the recognition of a judgment if it considers that the manifest deficiency remains even after the decision made by the CJEU upon a reference.

Even if there is no doubt as to the compatibility of EU law with the ECHR, the executing court must avoid an automatic and literal reading of mutual recognition that would undermine fundamental rights protection. This means that the court executing a judgment must make sure that a remedy exists against that judgment in the issuing country and that it can be exercised by the applicant. Nevertheless, the duty of the executing court depends on the circumstances of the case and the gravity of the fundamental right at stake. For example, in Avotinsšv. Latvia the ECrtHR did not find a manifest deficiency (only a regrettable shortcoming) although the adversarial principle and the principle of equality of arms guaranteed by Article 6(1) ECHR were at stake and the Latvia Supreme Court only assumed the existence and the availability of the remedy against the judgment in Cyprus. ${ }^{82}$

81 By contrast, Judge Ress's concurring Opinion in the Bosphorus Judgment observed that such a deficiency should exist as soon as the CJEU would lack jurisdiction, where the CJEU had been too restrictive in its interpretation of individual access, where there has been an obvious misinterpretation or misapplication by the ECJ of the guarantees of the Convention right, where the CJEU departed from settled case-law of the ECrtHR or where the level of protection in the CJEU did not leave up to the ECHR, see paragraph 3.

82 Mr Avotinss claimed that the summons for the hearing before the Cypriot court had never reached him. According to Article $34(2)$ of the Brussels I Regulation, such a situation would be a ground for the executing court to refuse the recognition of the foreign judgment provided the claimant exercised any remedy available against that judgment in the country of origin. In 
The Strasbourg Court sends here a message that the automaticity of mutual recognition must not be detrimental to fundamental rights. ${ }^{83}$ That is where the position of the ECrtHR seems to depart from that of the CJEU according to which the principle of mutual trust and mutual recognition

'requires, particularly with regard to the area of freedom, security and justice, each of those States, save in exceptional circumstances, to consider all the other Member States to be complying with EU law and particularly with the fundamental rights recognised by EU law. ${ }^{, 4}$

To date, the CJEU decides that such exceptional circumstances occur where the application of the principle of mutual trust and mutual recognition would entail a real risk of torture or degrading treatment (Article 4 CFR and 3 ECHR) of the person subject to the decision. For example, this is what happened in the N.S. Joined Cases. ${ }^{85}$ In these cases, the CJEU decided that the transfer of asylum seekers within the framework of the Dublin system may, in certain circumstances, be incompatible with the prohibition laid down in Article 4 CFR if this transfer would result in a serious risk of degrading treatment. However, the judgment was criticised for allowing a rebuttal of mutual trust only in cases of systemic deficiencies affecting the receiving country although the ECrtHR requires, where necessary, an individual assessment in the absence of systemic flaws. ${ }^{86}$ The CJEU here seems to have brought its position in line with the

the particular circumstances of the case, the Grand Chamber found that Mr Avotiņš had a clear possibility to challenge the Cypriot judgment in Cyprus as soon as he became aware of that judgment. He, however, did not use that right and therefore the Latvian Supreme Court did not have to refuse the recognition of that judgment in application of Article 34(2) of the Brussels I Regulation. The Latvian Supreme Court had adequately requested information from Cyprus concerning the remedy available against the judgment and did not breached the adversarial principle and the principle of equality of arms guaranteed by Article 6(1) ECHR, see Avotinš v. Latvia [GC], supra, paras. 121 and 122.

83 As was contended in literature, see for example V. Mitsilegas, 'The Limits of Mutual Trust in Europe's Area of Freedom, Security and Justice: From Automatic Inter-State Cooperation to the Slow Emergence of the Individual', supra.

84 Opinion 2/13, Accession of the European Union to the European Convention for the Protection of Human Rights and Fundamental Freedoms, supra, para. 191 (italics added).

85 Joined Cases C-411/10 and C-493/10, N. S. (C-411/10) v. Secretary of State for the Home Department and M. E. and Others (C-493/10) v. Refugee Applications Commissioner and Minister for Justice, Equality and Law Reform, EU:C:2011:865, paras. 86 to 94 and 106 where the CJEU ruled that the transfer of asylum seekers within the framework of the Dublin system may, in certain circumstances, be incompatible with the prohibition laid down in Article 4 CFR.

86 See Case C-394/12, Abdullahi, EU:C:2013:813, para. 60 and by contrast ECrtHR, 4 November 2014, Tarakhel v. Switzerland Application No. 29217/12; on this C. Costello, M. Mouzourakis, Reflexions on reading Tarakhel: Is 'How Bad is Bad Enough' Good Enough?, [2014] Asiel\&Migrantenrecht, 404 . 
ECrtHR in the C.K. case $\mathrm{e}^{87}$ where it held that even in the absence of such deficiencies, a transfer might result in a violation of Article 4 CFR.

Similarly, the CJEU decided in the Aranyosi and Caldararu Joined Cases that a court executing an EAW

'is bound to determine whether, in the particular circumstances of the case, there are substantial grounds to believe that, following the surrender of that person to the issuing Member State, he will run a real risk of being subject in that Member State to inhuman or degrading treatment, within the meaning of Art. $4 .{ }^{, 88}$

The CJEU justifies its reasoning in particular with the fact that the prohibition of inhuman or degrading treatment or punishment is absolute and is closely linked to the respect for human dignity (Article 1 CFR) ${ }^{89}$ By contrast, paragraph 114 of the Avotinš v. Latvia judgment, shows that the ECrtHR clearly considers that the rebuttal of mutual trust cannot be limited to exceptional circumstances. ${ }^{9}$ The ECrtHR imposes on national courts a duty to control the existence of a manifest deficiency with regard to any serious allegation of a violation of fundamental rights in the issuing country. The control therefore should be able to extend to any right protected by the ECHR. Nevertheless, I have contended elsewhere in the context of the EAW, that in practice, the divergence between the two European Courts is only theoretical. ${ }^{91}$ For example, it is rather unlikely that the enforcement of a EAW could be refused because of a risk of an Article 6 ECHR violation in the issuing country. ${ }^{92}$ In addition, following the Aranyosi and Caldararu Joined Cases, one can also conclude that the position of the CJEU is in line with the ECrtHR with regard to the consequences of a mutual trust's

87 Case C-578/16 PPU, C. K. and Others v. Republika Slovenija, EU:C:2017:127, para. 96; see on this case the following blogs: www.droit-union-europeenne.be/416703027; www.gdrelsj.eu/2017/03/o1/informations-generales/escale-a-canossa-la-protection-des-droits-fondamentaux-lors-dun-transfert-dublin-vue-par-la-cour-de-justice-c-k-c-slovenie-c-57816-ppu/.

88 Joined Cases C-404/15 and C-659/15 PPU, Pál Aranyosi and Robert Căldăraruv Generalstaatsanwaltschaft Bremen [GC], EU:C:2016:198, para. 94.

89 Joined Cases C-404/15 and C-659/15 PPU, Pál Aranyosi and Robert Căldăraruv Generalstaatsanwaltschaft Bremen [GC], supra, para. 85 and Case C-578/16 PPU, C. K. and Others v. Republika Slovenija, supra, para 59.

90 The Strasbourg Court refers to 'exceptional cases'.

$9^{1}$ T.P. Marguery, 'Rebuttal of Mutual Trust and Mutual Recognition in Criminal Matters: Is “Exceptional” Enough?’ [2016] European Papers 579. Available at: www.europeanpapers.eu, $943-963$.

92 In C-396/11, Ciprian Vasile Radu, EU:C:2013:39 the CJEU ruled out this possibility and an application of ECrtHR, 7 July 1989, Soering v. United Kingdom, Application No. 14038/88 to EAW would require a flagrant denial of justice in the application of Article 6 ECHR, which is a very high threshold to reach. See on this also Opinion of Advocate General Sharpston in C-396/11, Ciprian Vasile Radu, supra. 
rebuttal: mutual recognition must be set aside. The CJEU observed that the executing court must postpone the surrender of the person subject of the EAW and, if the risk in the issuing Member State remains the executing court must bring the surrender proceedings to an end in order to avoid that the detention of the fugitive violates Article 6 CFR and 5 ECHR..$^{93}$

\section{Conclusion}

The Avotinš v. Latvia judgment is certainly welcome because it clarifies the position of the ECrtHR after the refusal of the EU accession to the ECHR acted by the CJEU in Opinion 2/13. In this sense if it shows that the two European Courts are continuing their dialogue. The clash of the titans will not take place, at least not for now, and the Bosphorus 'compromise' is maintained. ${ }^{94}$ The ECrtHR also validates the presumption of mutual trust between Member States of the EU although this presumption coupled with the Bosphorus presumption implies that the intensity of the fundamental rights control may well be reduced in certain circumstances. This may be regrettable, as it does not encourage the best student in the class, i.e. the Member States with a high level of fundamental rights protection, to provide an opportunity to increase fundamental rights standards in Europe. The Strasbourg Court shows also a great deal of confidence in how national courts are taking fundamental rights seriously since the safeguards will first of all be a matter of Member State discretion. However, one might have expected a stronger stance with the ECrtHR over the use of the preliminary reference to the CJEU by national courts and over what exactly the manifest deficiency test imposes on these courts. These two questions will certainly be developed in the cases to come especially considering the importance of mutual trust in the AFSJ. In this respect, one must notice that the Avotinšs v. Latvia judgment concerns mutual recognition in civil matters and the protection of a fundamental right - Article 6 ECHR - that can be limited. Even if certain aspects of the judgment are very general, it is still unsure whether it can be applied by analogy to mutual recognition in other EU policy area such as criminal law and with regard to other fundamental rights. In particular, the ECrtHR's 'manifest deficiency' test seems at odds with the 'exceptional circumstances' imposed by the CJEU to rebut mutual trust only if there is a risk of violation of a non-derogable fundamental right.

Joined Cases C-404/15 and C-659/15 PPU, Pál Aranyosi and Robert Căldăraruv Generalstaatsanwaltschaft Bremen [GC], supra, para. 104.

94 See for a reference to a 'compromise', E. Spaventa, 'A very Fearful Court? The Protection of Fundamental Rights in the European Union after Opinion 2/13', [2015] Maastricht Journal of European and Comparative Law, 35-56. 